\title{
Twenty-six years of aspen regeneration under varying light conditions in a boreal mixedwood forest
}

\author{
by Holly D. Deighton ${ }^{1}$, Arthur Groot ${ }^{2, \pm}$, Nelson Thiffault ${ }^{3}$, and Mya Rice ${ }^{1 *}$
}

\begin{abstract}
Density, height, and diameter at breast height of trembling aspen (Populus tremuloides Michx.) sucker regeneration were assessed over a 26 -year period in openings created by harvesting in a 40-year-old aspen stand in northeastern Ontario (Canada). The opening types were 9- and 18-m diameter circles, 9- and 18- $\times 150$-m east-west strips, and a 100- $\times 150-\mathrm{m}$ clearcut, representing a range of light conditions. Density, height, and diameter at breast height of aspen regeneration were significantly affected by opening type, location relative to opening, and time since harvest. By year 26 , aspen densities in circular openings declined to 0 , despite high initial recruitment, and trembling aspen heights were significantly lower in the 9-m strips than in the 18-m strips or the clearcut. Year 26 aspen density, volume, and basal area increased with increasing initial light intensity, with the highest rate of increase between 80 and 100\% light levels. Understory vegetation cover was largely unaffected by opening size; however, substantial understory aspen regeneration occurred in the smaller openings. Results support the traditional view that aspen is best managed under the clearcut silvicultural system, and $>80 \%$ full light is recommended for adequate long-term aspen regeneration.
\end{abstract}

Keywords: Populus tremuloides Michx., silviculture, boreal mixedwoods, regeneration, forest openings, clearcut

\section{RÉSUMÉ}

La densité, la hauteur et le diamètre à hauteur de poitrine de la régénération issue de drageonnement du peuplier fauxtremble (Populus tremuloides Michx.) ont été évalués sur une période de 26 ans dans des trouées créées par la coupe dans une peupleraie de 40 ans située dans le nord-est de l'Ontario (Canada). Les trouées étaient de différents types: circulaires avec un diamètre de 9 ou $18 \mathrm{~m}$, des bandes d'orientation est-ouest de 9 et $18 \times 150 \mathrm{~m}$, et une coupes total de $100 \times 3150$ $\mathrm{m}$, créant un gradient de conditions lumineuses. La densité, la hauteur et le diamètre à hauteur de poitrine de la régénération de peuplier ont été influencés significativement par le type de trouée, la position par rapport aux trouées et le temps depuis la coupe. Après 26 ans, la densité du peuplier dans les trouées circulaires est devenue nulle, malgré un recrutement initial élevé. La hauteur du peuplier était significativement plus basse dans les bandes de $9 \mathrm{~m}$ que dans les bandes de 18 $\mathrm{m}$ ou les coupes totales. La densité du peuplier, le volume et la surface terrière ont augmenté avec l'intensité; la plus forte augmentation a été observée entre $80 \%$ et $100 \%$ de pleine lumière à l'année 26 . Le recouvrement de la végétation de sous-bois a été peu affecté par la dimension des trouées. Cependant, on a constaté une plus forte régénération de peuplier sous couvert dans les plus petites trouées. Les résultats soutiennent que l'approche traditionnelle basée sur la coupe totale est la plus appropriée pour l'aménagement du peuplier et qu'une proportion $>80 \%$ de pleine lumière est recommandée pour assurer la régénération à long terme de l'essence.

Mots-clés: Populus tremuloides Michx., sylviculture, forêts mixtes boréales, régénération, trouées, coupe totale

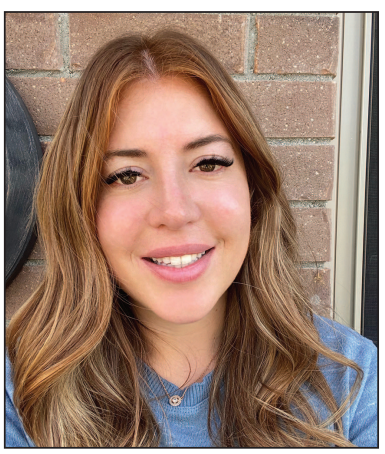

Holly D. Deighton

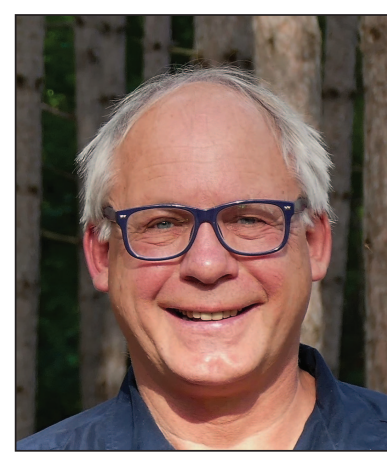

Arthur Groot

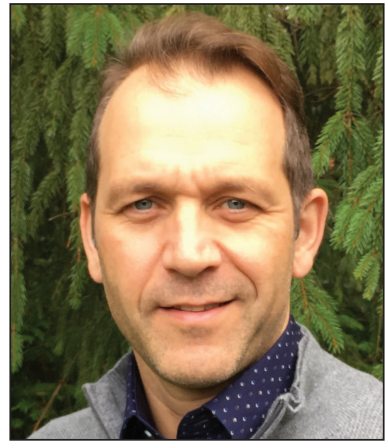

Nelson Thiffault

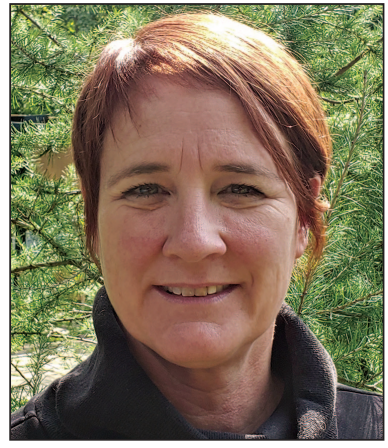

Mya Rice

${ }^{1}$ Ontario Forest Research Institute, Ontario Ministry of Northern Development, Mining, Natural Resources and Forestry, 1235 Queen St. East, Sault Ste. Marie, Ontario P6A 2E5, Canada; * corresponding author: mya.rice@ontario.ca

${ }^{2}$ Canadian Wood Fibre Centre, Canadian Forest Service, Natural Resources Canada, 1219 Queen St. East, Sault Ste. Marie, Ontario P6A 2E5, Canada; ${ }^{ \pm}$Retired

${ }^{3}$ Canadian Wood Fibre Centre, Canadian Forest Service, Natural Resources Canada, 1055 du P.E.P.S., P.O. Box 10380, Sainte-Foy Stn., Québec City, Québec G1V 4C7, Canada 


\section{Introduction}

Trembling aspen (Populus tremuloides Michx.) is the most widespread native tree species in North America (Barnes 1975). Aspen occurs in a variety of forest types throughout its range, including mixedwood stands in the Lake States and the Canadian boreal forest and single species stands throughout the western mountains of the United States and the Canadian parkland (Perala and Russell 1983; Rogers et al. 2014). In the Canadian boreal mixedwood forest, aspen is common on mesic upland sites associated with morainal deposits in the east (excluding the clay belt; Rowe 1972), lacustrine or morainal deposits in the prairie provinces, and drier sites associated with colluvial deposits west of the Rocky Mountains (Bergeron et al. 2014).

The mixedwood forest is highly productive, an important source of fibre, and was historically harvested for white spruce (Man and Lieffers 1999). In the early 1980s, a market increase in production/use of structural panels and particle board (Perala 1990) resulted in growing demand for aspen in Canada and the Lake States (Einspahr and Wyckoff 1990), as well as in the western interior of the United States (Rogers 2002). Over the last 30 years, advances in oriented strand board technology and pulp and paper production have further increased demand for aspen (Rogers et al. 2014), intensifying the importance of understanding aspen silviculture and ecology to make well informed forest management decisions, especially in the boreal mixedwood forest type (Man and Lieffers 1999).

Aspen mainly regenerates via root suckering (Frey et al. 2003) and less frequently from seed (Pinno and Errington 2015). Mechanisms regulating sucker initiation and development are related to several stimuli, such as apical dominance (Farmer 1962) and soil temperature (Fraser et al. 2002). Apical dominance controls sucker development on roots through the regulation of auxin, which suppresses sucker bud initiation (Eliasson 1971), and cytokinin, which is associated with shoot development on roots (Peterson 1975). After disturbance, increased soil and root temperatures indirectly stimulate sucker initiation (Frey et al. 2003), which promotes auxin degradation (Schier et al. 1985) and encourages cytokinin synthesis and root growth (Williams 1972). Light may also indirectly influence the regulation of sucker development. High light environments increase soil and root temperatures, stimulating aspen growth; whereas low light environments limit the production of photosynthate (Frey et al. 2003) or increase carbon allocation to the root system, significantly decreasing sucker growth in young aspen (Landhäusser and Lieffers 2001). Regenerating suckers have live roots often connected to the stump of dead and decayed trees and incorporate the parent roots into their own root systems (DesRochers and Lieffers 2001). Silvicultural methods that fully (or nearly fully) remove the overstory are considered most suitable for aspen management (Huffman et al. 1999; Berrill et al. 2017).

The response of aspen regeneration and growth to complete (or near complete) overstory removal is well documented (Groot et al. 2009). The number of stems left after harvesting is inversely related to aspen regeneration (Schier et al. 1985; Doucet 1989; Huffman et al. 1999; Brais et al. 2004; Man et al. 2008; Lennie et al. 2009), with most suckers produced in the first growing season after distur- bance (Bell et al. 1999). Evidence exists, however, of gap dynamics in boreal aspen stands, with adequate aspen regeneration occurring in gaps as small as $50 \mathrm{~m}^{2}$ (Cumming et al. 2000; Moulinier et al. 2011). Indirect evidence exists for gaps influencing the establishment of unevenaged aspen stands in eastern Canadian boreal forests (Namroud et al. 2005). In single cohort stands, unharvested older stands die off, lose the forest canopy, regenerate, and take 60 years to acquire significant volume for harvesting (LeBlanc 2014). In contrast, multi-cohort stands resulting from gap dynamics, drought, or insect outbreaks that have killed off portions of the mature canopy (Cumming et al. 2000) may retain sufficient volume to harvest after stand break-up begins, and avoid the lengthy period between harvests (LeBlanc 2014). The occurrence of aspen gap dynamics and multi-cohort stands raises the possibility that aspen could be managed by use of alternatives to clearcutting (i.e., partial harvesting or the creation of small openings; Groot et al. 2009). In recent years, researchers have addressed the effects of aspen regeneration and retention after partial harvesting (Gradowski et al. 2010; Solarik et al. 2012; Bose et al. 2014a), but work is limited on the effects of aspen regeneration after the creation of small openings (Groot et al. 1997, 2009; Kabzems 2001).

Results related to how much light is needed to allow for adequate aspen regeneration are conflicting. Light is not directly needed for sucker initiation, but it is needed for secondary growth (Perala 1990). Silviculture guides (e.g., Ministry of Natural Resources and Forestry 2015) typically suggest that light demanding species, such as aspen and jack pine (Pinus banksiana Lamb.), establish regeneration in $>70 \%$ full sunlight. However, short-term ( $<3$ years) studies in Canada show aspen regeneration in gaps as small as $254 \mathrm{~m}^{2}$ (estimated $<55 \%$ full light at opening centre) in northeastern Ontario (Groot et al. 1997), $314 \mathrm{~m}^{2}$ in northern British Columbia (Kabzems 2001), and $400 \mathrm{~m}^{2}$ in Quebec (Lavertu et al. 1994). Ten-year results also confirmed sustained aspen growth and densities in openings that allow $>55 \%$ full light at the opening centre (Groot et al. 2009). The time-dependent mortality pattern of aspen and its interaction with initial canopy light conditions (Groot et al. 2009; Man et al. 2008), as well as ambiguous research results and operational experience, highlight the need for longer-term examination of aspen regeneration and growth patterns.

Our objectives were to examine how the density and growth of aspen regeneration in small forest openings are influenced by the size and location of regeneration relative to the edge of the opening and by time since harvest. We analyzed long-term data (26 years) from an experiment in which several sizes and configurations of openings were created in a trembling aspen-dominated forest. Mid-term results $\left(10^{\text {th }}\right.$ year) were previously reported (Groot et al. 2009), and we expected a long-term continuation of the identified trends. Specifically, we hypothesized that, (i) although initial aspen regeneration occurred in all openings, regenerated aspen would persist only in larger openings with more available light, and (ii) regenerated aspen density and growth would be highest in the clearcut treatment relative to the other treatments. We also hypothesized that shade-tolerant shrubs (mainly Acer spicatum Lamb. and Corylus cornuta Marsh.) would be abundant throughout the openings. 


\section{Materials and methods}

\section{Site description and experimental treatments}

The experiment was established in 1993 on a study site located in Halsey Township, $25 \mathrm{~km}$ southeast of Chapleau, Ontario $\left(47^{\circ} 43^{\prime} \mathrm{N}, 83^{\circ} 11^{\prime} \mathrm{W}\right.$; Groot et al. 1997). At the time of establishment, the study site was in a 40 -year-old mixedwood stand that originated after harvesting. The stand had a dominant tree height of $19 \mathrm{~m}$ and a basal area of $36 \mathrm{~m}^{2} \mathrm{ha}^{-1}$ and was dominated by trembling aspen (84\% of the basal area), but also included balsam fir (Abies balsamea (L.) Mill. - 7\%), white birch (Betula papyrifera Marsh. - 7\%), and white spruce (Picea glauca (Moench) Voss - 1\%). Density of stems $>10 \mathrm{~cm}$ diameter at breast height (DBH) was 1570 $\mathrm{ha}^{-1}$. Understory vegetation at the time of site establishment included herbs, ferns, and shrubs (i.e., Aster macrophyllus L., A. ciliolatus Lindl., Pteridium aquilinum L. Kuhn, Corylus cornuta, and Diervilla lonicera Mill.) and balsam fir. Soils were deep, fresh, well-drained silts, with local concentrations of boulders and cobbles in the top $50 \mathrm{~cm}$. In 2019, the stand had a dominant tree height of $22.6 \mathrm{~m}$ and a basal area of 32.4 $\mathrm{m}^{2} \mathrm{ha}^{-1}$ and was dominated by trembling aspen ( $68 \%$ of the basal area), but also included white birch (17\%), balsam fir $(12 \%)$ and minor components of white $(2 \%)$ and black spruce (Picea mariana (Mill.) BSP $<1 \%$ ). Density of stems $\geq$ $10 \mathrm{~cm}$ diameter at breast height was $734 \mathrm{ha}^{-1}$ in 2019.

In February and March 1993, the study site was harvested to create five sizes of openings designed to create a range of environmental conditions: six 9-m diameter circles, six 18 -m diameter circles, three $9-\times 150$-m east-west strips, three $18 \times 150$-m east-west strips, and a clearcut $(100 \times 150$ $\mathrm{m})$. The openings corresponded to a range of light conditions of about $26,55,57,68$, and 100 of full light at opening centre for the 9- and 18-m diameter circles, 9- and 18- $\times 150$-m eastwest strips, and the clearcut, respectively. Measurement plots were laid in one $\mathrm{E}-\mathrm{W}$ line and one N-S line in circular openings, and in three N-S lines in each of the strip and clearcut openings (Supplementary Fig. S1). For detailed site description and plot layout, see Groot et al. (1997). No residual stems were left in the openings. Deep snow cover at time of harvesting precluded disturbance of the soil surface.

\section{Initial canopy light measurements}

Solar irradiance was measured in the first year after harvest in 1993 at the centre of the clearcut, underneath the intact forest canopy, and at several positions in one replicate of each of the strip and circular openings [for details about sensors and positions, see Carlson and Groot (1997) and Groot et al. (1997)]. For each sensor position, the mean initial proportion of above canopy light (PACL) was determined for 13 June to 8 July 1993, a period free of data gaps for all sensors. Because sensor positions did not coincide with the aspen plot centres, PACL values for the aspen plot positions were estimated by linear interpolation between sensor positions (Supplementary Table S1).

Aspen regeneration measurements and vegetation assessment Trembling aspen density $\left(\right.$ stems ha $\left.{ }^{-1}\right)$, height $(\mathrm{m})$, and DBH $(\mathrm{cm})$ of regeneration $>130 \mathrm{~cm}$ were measured in each plot at the end of the $1^{\text {st }}, 2^{\text {nd }}, 4^{\text {th }}, 6^{\text {th }}, 8^{\text {th }}, 10^{\text {th }}$, and $26^{\text {th }}$ growing season after harvest. For details about plot measurements until the $10^{\text {th }}$ growing season after harvesting, see Groot et al.
(2009). At the time of site establishment, 356 plots were available to measure. Plots in the E-W transects outside (i.e., forest adjacent to the harvest treatment) the circular openings were assessed only after the first and second growing seasons (Groot et al. 2009). One plot was omitted from the measurements after seasonal standing water was noted in the opening, two plots could not be identified, and 20 plots could not be remeasured as they had recently been clearcut. Thus, 290 plots were measured in 2019.

Vegetation was assessed the week of 7 July 2019. Each measurement plot was used to identify and estimate abundance (visual estimation of per cent cover) of vegetation. Vegetation was grouped by layers, and per cent cover in each layer was assessed independently from others. The vegetation layers were overstory regeneration (tree height $>4 \mathrm{~m}$ from ground), understory regeneration (tree height $<1.3 \mathrm{~m}$ and $\leq 4 \mathrm{~m}$ from ground), shrub (all woody shrub species), ferns (ferns and allies), graminoids (grasses and sedges), herbs (herbaceous plants), mosses, lichens, coarse wood (any downed wood $>7.5 \mathrm{~cm}$ in diameter), fine wood (any downed dead wood $\leq 7.5 \mathrm{~cm}$ in diameter), and stumps. For trees to be considered in the measurement plot, a minimum of half of the stem at germination had to breach the circumference of the assessment plot. Per cent cover was estimated at $0,1,5$, and $10 \%$, then in increments of 10 up to $100 \%$.

\section{Statistical analysis}

The experiment was established as a complete randomized design with repeated measures over time after harvesting. Although the N-S lines in the clearcut and strip openings were not independent replicates, they were separated by a large distance $(\sim 36 \mathrm{~m})$. As it was not feasible at the time to replicate the clearcut treatment, each N-S line in the clearcut and both strip openings was considered a replicate to allow the clearcut treatment to be included in the statistical analysis. Using this design, total replication was five for the 9-m circles, six for the $18-\mathrm{m}$ circles, nine for the $9-\mathrm{m}$ and $18-\mathrm{m}$ strips, and three for the clearcut. This design increases the risk that effects of opening type are confounded with location (Hurlbert 1984), but this possibility is reduced by the large distance between replicates.

Statistical analyses were performed with R statistical software version 4.0.3 (R Core Team 2020). Two-way analysis of variance (ANOVA) with planned orthogonal contrasts was used to determine the effect of opening type and location on aspen density, total height, and DBH 26 years after harvesting. Normality was assessed using histograms and ShapiroWilk's normality test and homogeneity of variances was assessed using Bartlett's test. Unless otherwise stated, values reported in the results represent original values. Fixed variables included opening type (9-m circle, $18-\mathrm{m}$ circle, 9-m strip, 18-m strip, 100-m clearcut) and location (inside and outside opening). Orthogonal contrasts were performed when fixed factors or interactions were significant $(p<0.05)$. The orthogonal contrasts were used to compare response variables between treatments (clearcut vs. strips, clearcut vs. circles, strips vs. circles, 9-m vs. 18 -m strip, 9-m vs. 18 -m circle) and within treatments (inside vs. outside opening). Before the ANOVA, density, height, and DBH of aspen $(>1.3$ $\mathrm{m}$ height) were averaged across regeneration plots (weighted means for height and DBH based on density; Groot et al. 
Table 1. Summary of P-values from analysis of variance (ANOVA) for density, total height, and diameter at breast height (DBH; 1.3-m) of aspen regeneration 26 years after harvesting in a mixedwood forest in northeastern Ontario, Canada. Planned orthogonal contrasts were computed only if main effects of treatment or location were significant.

\begin{tabular}{|c|c|c|c|c|c|c|}
\hline \multirow[b]{2}{*}{ Sources of variation } & \multicolumn{2}{|c|}{ Density } & \multicolumn{2}{|c|}{ Height } & \multicolumn{2}{|c|}{ DBH } \\
\hline & DF & $p$ & $\mathrm{DF}$ & $p$ & DF & $p$ \\
\hline Opening type $(\mathrm{O})$ & 4 & $<0.001$ & 3 & 0.010 & 3 & 0.047 \\
\hline Clearcut vs. strips & 1 & 0.736 & 1 & 0.064 & 1 & 0.096 \\
\hline Clearcut vs. circles & 1 & $<0.001$ & 1 & $<0.001$ & 1 & $<0.001$ \\
\hline 9-m vs. 18 -m strips & 1 & 0.049 & 1 & 0.142 & 1 & 0.196 \\
\hline 9 -m vs. 18 -m circles & 1 & 0.879 & 1 & 0.641 & 1 & 0.636 \\
\hline 18 -m strip vs. 18 -m circle & 1 & 0.011 & 1 & $<0.001$ & 1 & $<0.001$ \\
\hline 9-m strip vs. 9-m circle & 1 & 0.510 & 1 & 0.064 & 1 & 0.064 \\
\hline Location (inside or outside opening) (L) & 1 & $<0.001$ & 1 & $<0.001$ & 1 & $<0.001$ \\
\hline In vs. Out in clearcut & 1 & $<0.001$ & 1 & $<0.001$ & 1 & $<0.001$ \\
\hline In vs. Out in $18-m$ strip & 1 & 0.002 & 1 & 0.010 & 1 & 0.003 \\
\hline In vs. Out in 18 -m circle & 1 & - & - & - & - & - \\
\hline In vs. Out in 9-m strip & 1 & 0.216 & 1 & 0.100 & 1 & 0.105 \\
\hline In vs. Out in $9-\mathrm{m}$ circle & 1 & - & - & - & - & - \\
\hline $\mathrm{O} \times \mathrm{L}$ & 4 & $<0.001$ & 2 & 0.274 & 2 & 0.140 \\
\hline
\end{tabular}

Note: - = absence of trees precluded computation of planned contrasts; $\mathrm{DF}=$ degrees of freedom

2009). Small regeneration $(<1.3 \mathrm{~m})$, hereafter referred to as new regeneration, was present in some plots in 2019'; it was analyzed separately since the purpose of this study was to assess how opening type affected the initial regeneration after harvesting, hereafter referred to as disturbance regeneration.

For each of the openings, the effect of position over time after its creation was examined through 2-way repeated measures ANOVA. Density and height were separated into 4 positions based on location relative to the opening centre: 1) north-inside, 2) north-outside, 3) south-inside, and 4) south-outside. Differences between opening positions (1 vs. 3 and 2 vs. 4) were obtained using the emmeans package. Plots at the centre of openings were excluded from the position analysis. One-way ANOVA was used to determine the relationship between per cent vegetation cover and opening type. Differences among opening types were assessed with Tukey's honest significant difference (HSD) test $(p . a d j<0.01)$ when a significant treatment effect $(p<0.05)$ was found.

Generalized additive models (GAMs) were used to relate mean response variables at year 26 (height, $\mathrm{DBH}$, density, volume, or basal area) to the predictor variable (initial PACL) using the GAM function in the package $m g c v$. GAMs can be used for highly non-linear relationships between response and predictor variable(s) and are an efficient tool to aid in the development of ecological models that better represent the underlying data (Guisan et al. 2002). GAMs use a link function to establish a relationship between the mean of the response variable and a 'smoothed' function of the predictor variable. The structure for each GAM can be visualized as:

${ }^{1}$ Short-lived aspen suckers often initiate under established overstories but generally die from lack of light (Perala 1991)

$$
g[E(Y)]=\sum_{i=1} a+f_{i}\left(x_{i}\right)
$$

where:

$g(Y)$ is the known link function (identity or logit) that links the expected value to the predictor variables

$E(Y)$ is the expected value

$f_{j}$ is the smooth function to be estimated

$x_{i}$ is the predictor variable

The gam.check function was used for model checking by creating a qqplot of the residuals to look for violations of mean variance and independence and determining if the basis dimension used for each smooth was correct. Height and $\mathrm{DBH}$ were modelled using a Gaussian distribution and density, volume, and basal area were modelled using a Poisson distribution. Likelihood ratio tests were used to assess model fit (using the lrtest function in the package lmtest) and significance of the smoothed function was found at $p<0.05$. GAMs were also used to model the relationship between new regeneration and disturbance regeneration density.

\section{Results}

Disturbance regeneration density

Aspen regeneration density was significantly affected by opening type and location (inside or outside opening; Table 1). Over the study period, the clearcut had the highest regeneration densities, followed by the 9- and 18-m strips and the 9- and 18-m circles (Fig. 1). Orthogonal contrasts revealed significant differences between the clearcut and circular openings and between the strip and circular openings. Initial regeneration densities were highest in year 1 (11300 to 

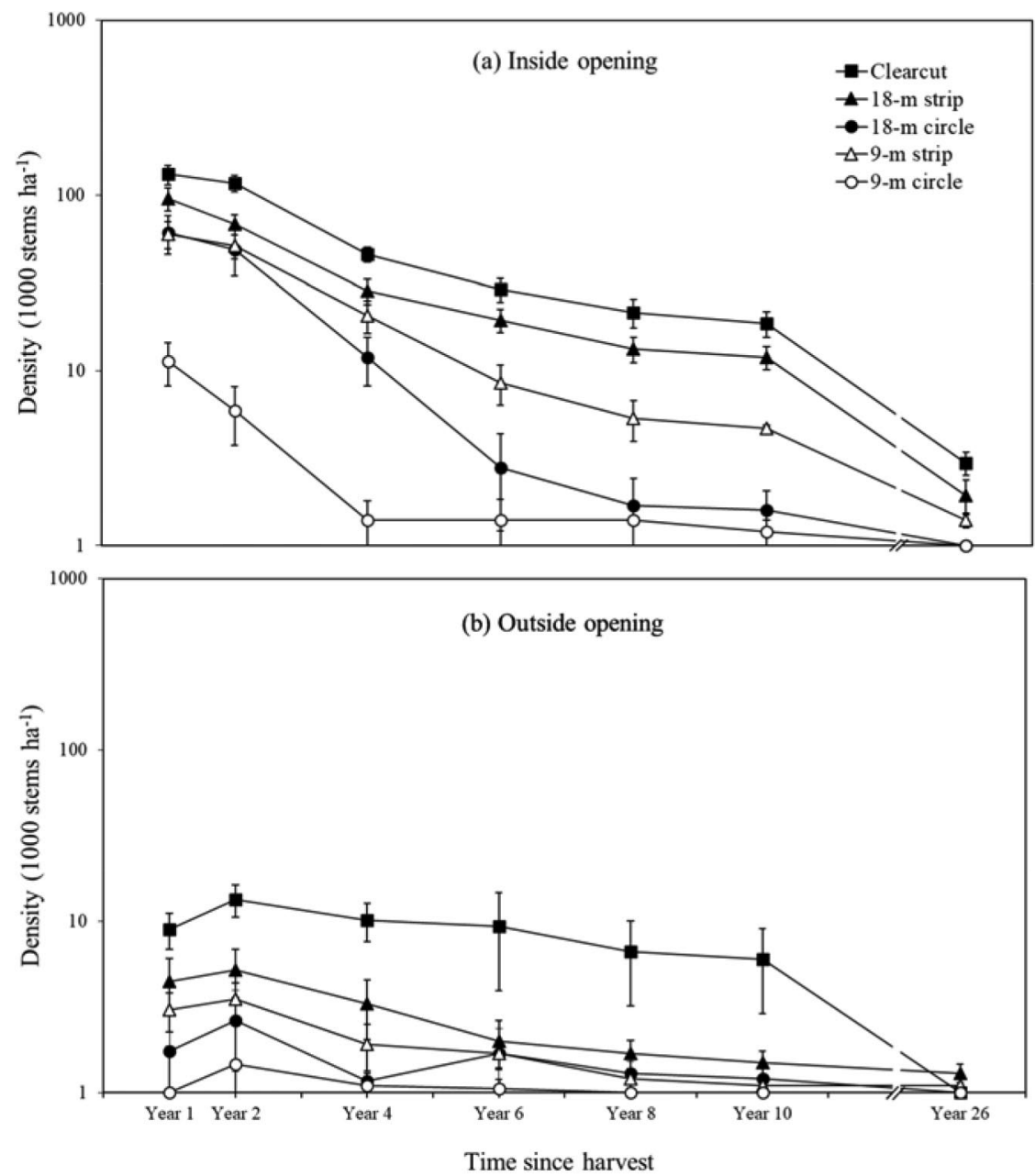

Fig. 1 Temporal trends of aspen regeneration density (log scale) by opening type and location a) inside or b) outside opening in a mixedwood forest stand in northeastern Ontario, Canada. Analyses were conducted for data collected at year 26; trends over time are shown for information purpose only. Note: adapted from Groot et al. 2009.

131400 stems ha $^{-1}$ inside openings) and (1000 to 9000 stems $\mathrm{ha}^{-1}$ outside openings) and decreased steadily over time (Fig. 1a). The number of regenerating stems decreased by more than $97 \%$ and by year 26 , only 162 regenerating stems were counted inside openings for all openings combined. Average regeneration densities inside the clearcut, $18-\mathrm{m}$ strips, and 9-m strips were 2968, 1940, and 422 stems ha- $^{-1}$, respectively, and the 18- and 9-m circular openings had no aspen stems present at year 26. Outside openings, regeneration densities were highest in year 2 and decreased steadily over time (Fig. 1b). By year 26, no aspen stems were present outside the 18 -m circles, one was present outside the clearcut, one was present outside one of the 9-m circular openings, and three were present outside the $9-\mathrm{m}$ strip openings. Outside the $18-\mathrm{m}$ strips, by year 26 aspen density decreased by more than $93 \%$ to 306 stems ha ${ }^{-1}$. Both inside and outside the openings, regeneration densities were generally higher on the north side than on the south side of the opening over time (Fig. 2). Clearcut and 18-m strip densities averaged 1568 and 2774 stems ha ${ }^{-1}$ higher in the north side versus the south side of the openings by year 26 ; however, differences were not significant for any opening type (Supplementary Table S2).

\section{Disturbance regeneration height and diameter}

Aspen regeneration height and $\mathrm{DBH}$ were significantly influenced by opening type and location (inside or outside opening; Table 1). Orthogonal contrasts revealed significant differences between the clearcut and strip openings and between the clearcut and circular openings. The clearcut and 18-m strip openings had similar mean regeneration heights 

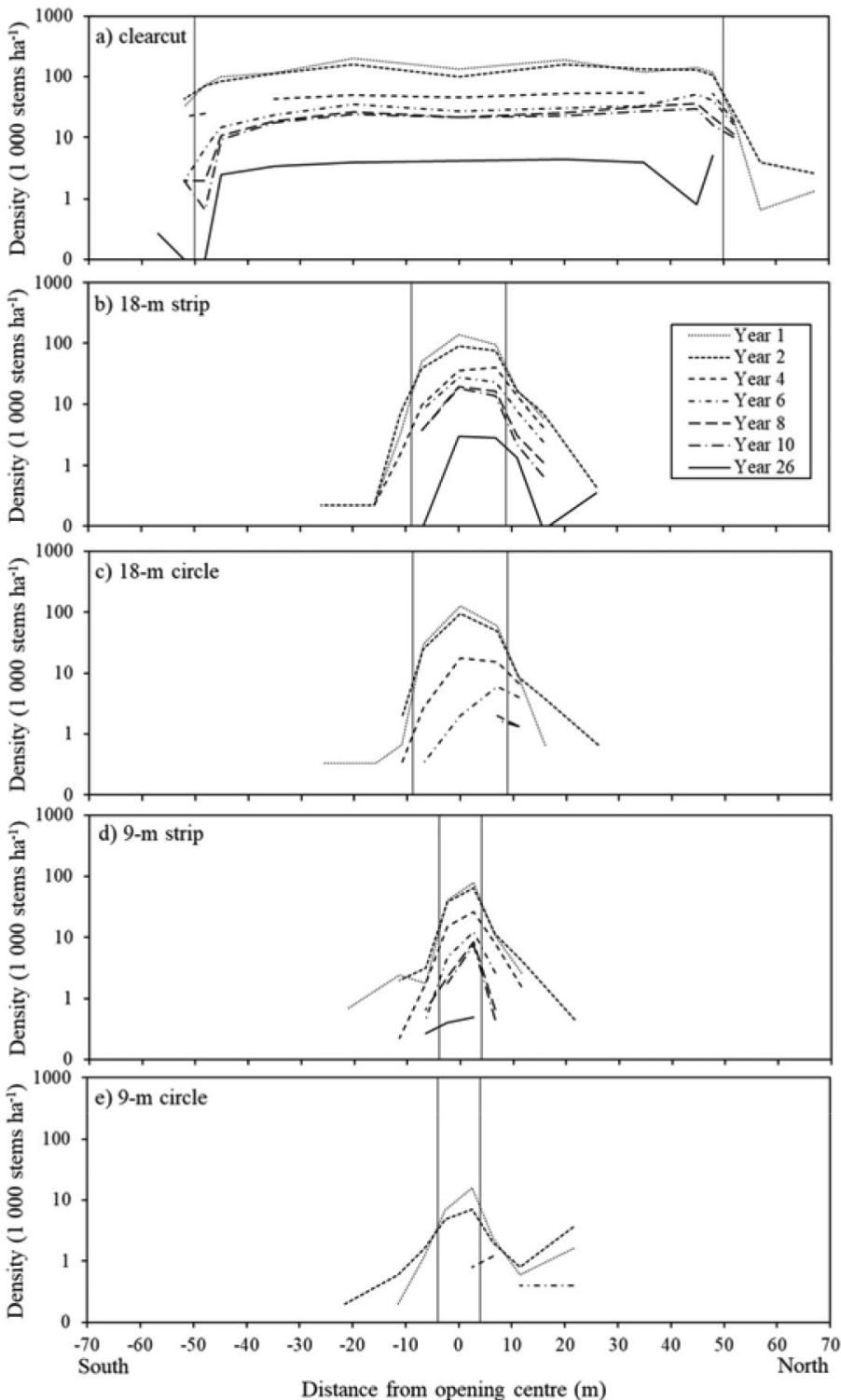

Fig. 2 Trembling aspen regeneration density (log scale) in north-south transects across 5 opening types in a mixedwood forest stand in northeastern Ontario, Canada. Solid vertical lines indicate the edge of the opening. Note: adapted from Groot et al. 2009 .

and $\mathrm{DBHs}$ over time and regeneration height and $\mathrm{DBH}$ increased with time in the clearcut and both strips (Figs. 3-4). By year 26, average regeneration height inside openings was $12.9 \mathrm{~m}(n=94)$ for the clearcut, compared with $12.6 \mathrm{~m}(n=59)$ and $10.1 \mathrm{~m}(n=9)$ for the 18 - and 9-m strips (no aspen stems were present in the circles) (Fig. 3). Inside the clearcut, regeneration height increased from the intact forest into the open- ing and reached maximum values of $15 \mathrm{~m}$ from the opening edge (Fig. 5a). In the clearcut treatment, the tallest regeneration stem recorded was $20.4 \mathrm{~m}$ tall with a DBH of $18.1 \mathrm{~cm}$ and the height of the tallest regeneration stems per plot averaged $15.6 \mathrm{~m}$. Inside and outside openings, differences in average height between the north and south sides were not significant (Supplementary Table S2; Fig. 5), except in the 18-m strips at year 26 , where stems in the north half of the opening were $1.12 \mathrm{~m}$ taller than those in the south half (Fig. 5b).

\section{Initial proportion of above canopy light}

GAMs revealed significant $(p<0.05)$ relationships with initial PACL for the $26^{\text {th }}$ year response variables height, density, volume, and basal area (Table 2). Diameter at breast height was the only variable assessed for which a significant relationship with PACL was not observed. GAMs based on individual aspen stems $(n=187)$ as the experimental unit explained less deviance (9-20\%) than those based on plots ( $n=262 ; 47-57 \%)$. Disturbance regeneration height and $\mathrm{DBH}$ increased with increasing PACL until PACL was 0.3 , whereas height and DBH remained relatively unchanged until PACL was 1.0 (Fig. 6a-b). Based on GAMs, mean response for disturbance regeneration density, volume, and basal area increased for PACL between 0 and 0.4 , however, the highest rates of increase occurred between PACL 0.8 and 1.0 (Fig. 6c-e). For example, from PACL 0-0.4 disturbance regeneration volume increased by $8.75 \mathrm{~m}^{3} \mathrm{ha}^{-1}$ per 0.1 PACL $\left(0-35 \mathrm{~m}^{3} \mathrm{ha}^{-1}\right)$; whereas from PACL $0.8-1.0$ disturbance regeneration volume increased by $70 \mathrm{~m}^{3} \mathrm{ha}^{-1}$ per 0.1 PACL $\left(50-190 \mathrm{~m}^{3} \mathrm{ha}^{-}\right.$ $\left.{ }^{1}\right)$. At PACL 0.8 , mean disturbance regeneration density, volume, and basal area were higher than $85-87 \%$ of the data set, whereas at PACL 1.0, disturbance regeneration density, volume and basal area were higher than $95-96 \%$ of the data set.

\section{Vegetation in openings}

Many new regeneration stems $(<1.3 \mathrm{~m}$ height; $n=163$ ) were present inside openings 26 years after harvest. GAMs revealed a significant relationship $(p<0.001)$ for the response variable new regeneration density with disturbance regeneration density (>1.3 m height; Table 2$)$. The average density of new regeneration stems decreased with increasing disturbance regeneration, and generally decreased with opening size (Fig. 7). For example, new regeneration densities averaged 4000, 1067, and 327 stems ha $^{-1}$ in the circular, strip, and clearcut openings, respectively. 

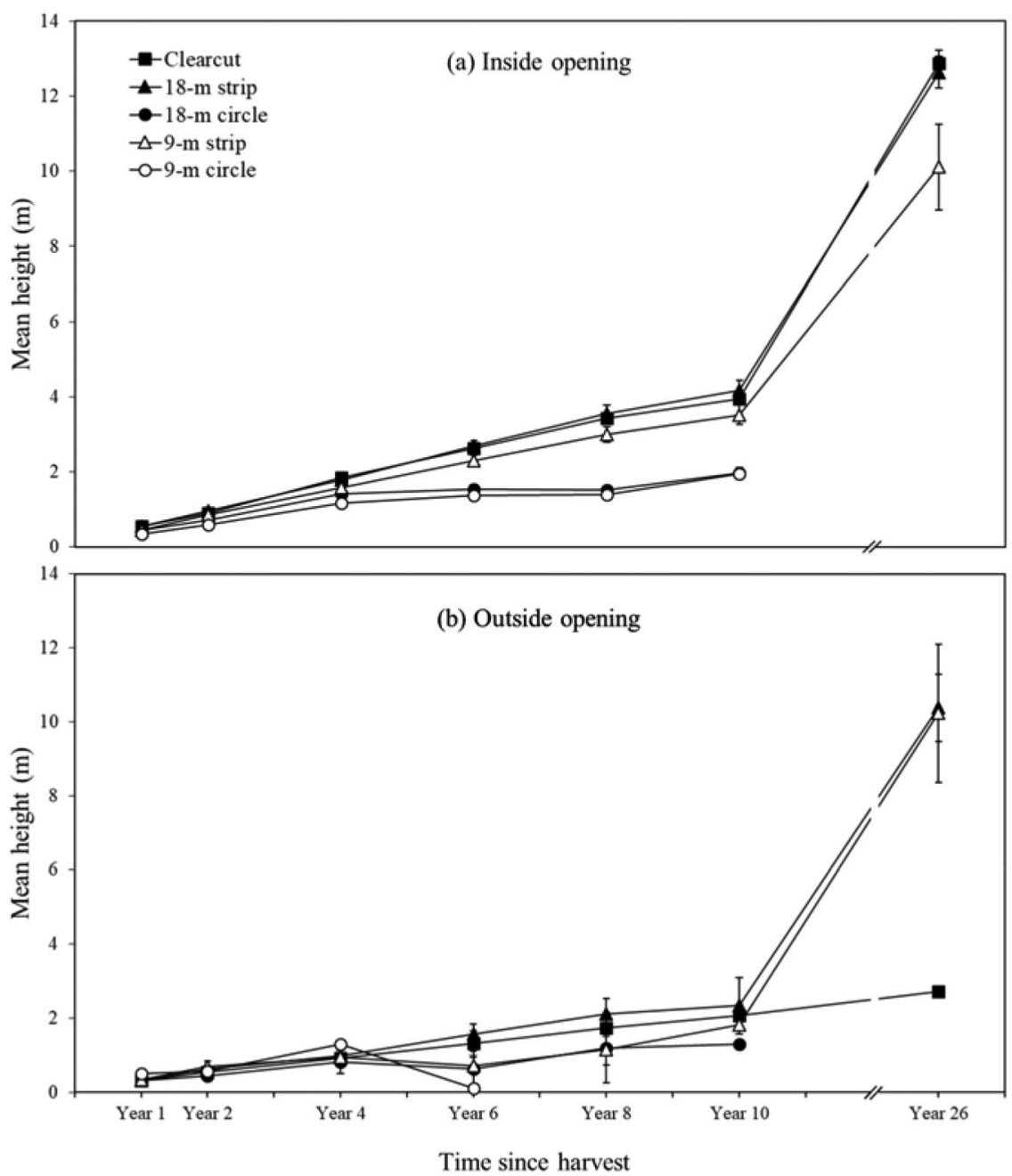

Fig. 3 Temporal trends of aspen regeneration height (least square mean) by opening type and location a) inside or b) outside opening in a mixedwood forest stand in northeastern Ontario, Canada. Analyses were conducted for data collected at year 26; trends over time are shown for information purpose only. Note: adapted from Groot et al. 2009.

Overall species composition of the regeneration varied by treatment (Supplementary Table S3). Overstory disturbance regeneration inside the openings was dominated by aspen (62\%) followed by white birch (19\%), balsam fir (17\%), and minor components of spruce $(<2 \%)$ (Data not shown). Aspen was the dominant overstory component in the clearcut (70\%) and 18-m strip (66\%) openings, but not in the 9-m strip (36\% aspen; balsam fir dominated at 38\%) or $18-\mathrm{m}$ circular openings ( $0 \%$ aspen; balsam fir/white spruce dominated at 50\% each). The 9-m circular openings had a combined total of just two overstory disturbance regeneration stems (one white spruce, one black spruce). Understory disturbance regeneration inside the openings was dominated by balsam fir (51\%) followed by aspen (29\%), white spruce
(13\%), and minor components of black spruce and white birch (>1\%) (Data not shown). Most of the balsam fir understory stems $(87 \%)$ were found inside the clearcut or strip openings.

Treatment effect was significant on overstory $\left(\mathrm{F}_{4,85}=4.59\right.$; $p=0.002)$ and understory disturbance regeneration $\left(\mathrm{F}_{4,85}=\right.$ $6.54 ; p<0.001)$ vegetation cover inside openings. Tree cover mostly decreased with decreasing opening size, and post hoc analysis revealed clearcut openings had significantly higher overstory and understory disturbance regeneration than both the 9-m and 18-m circular openings (Tukey's HSD Test; $p$.adj $<0.01$; Supplementary Fig. S2a-b). One-way ANOVA revealed no treatment effect on woody shrub $\left(\mathrm{F}_{4,85}=1.94 ; p\right.$ $=0.111)$ or herbaceous $\left(\mathrm{F}_{4,85}=1.79 ; p=0.139\right)$ vegetation 

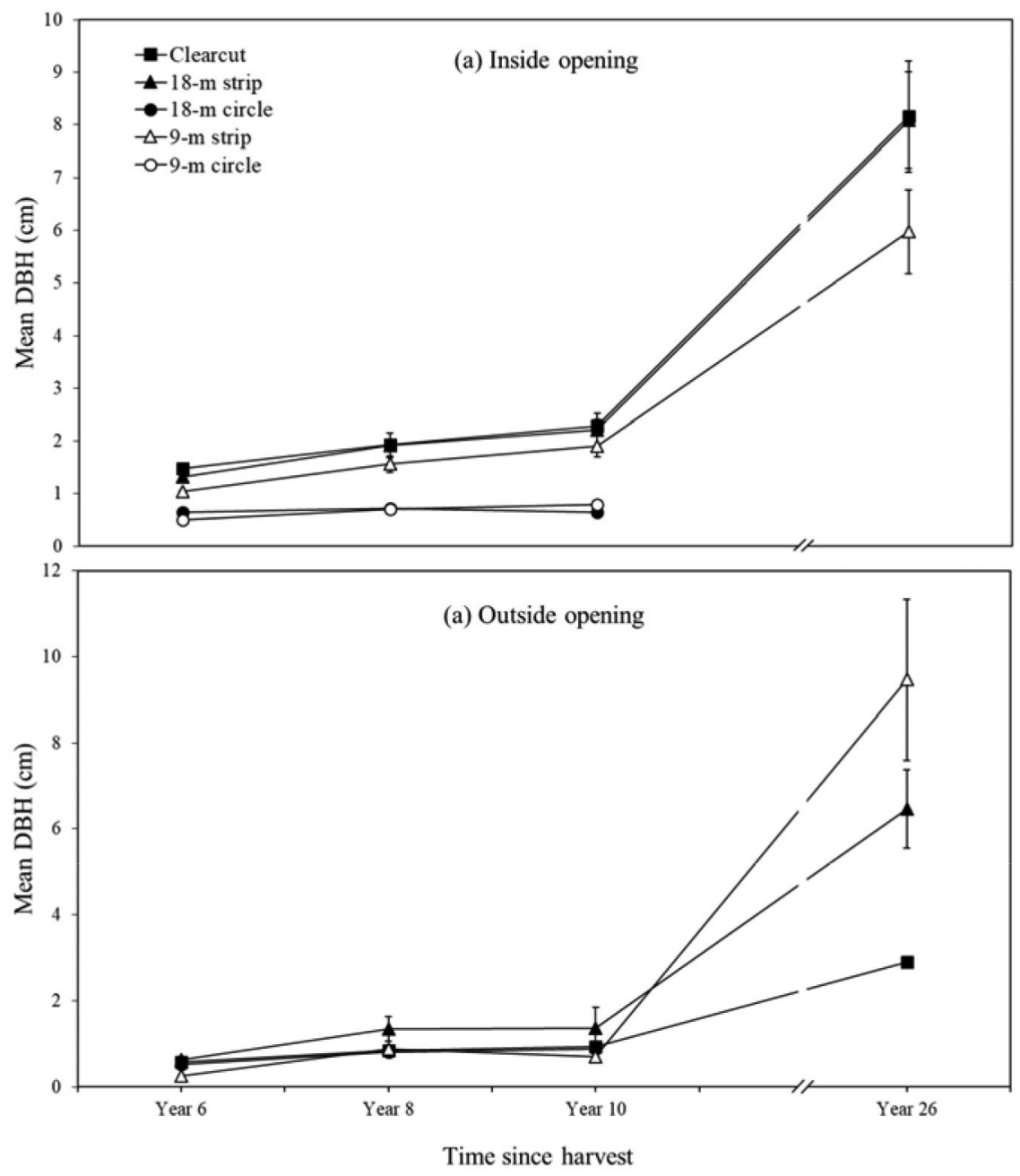

Fig. 4 Temporal trends of aspen regeneration diameter at breast height ( $\mathrm{DBH} ; 1.3 \mathrm{~m}$ ) (least square mean) by opening type and location a) inside or b) outside opening in a mixedwood forest stand in northeastern Ontario, Canada. Analyses were conducted for data collected at year 26; trends over time are shown for information purpose only. Note: adapted from Groot et al. 2009.

cover (Supplementary Fig. S2c-d); however, herbaceous cover mostly decreased with decreasing opening size and woody shrub cover was highest in medium openings (18-m circle and 9-m strips).

\section{Discussion}

\section{Disturbance regeneration density}

Although initial aspen regeneration occurred in all openings, regenerated aspen only persisted in larger openings that had higher initial light availability. Highest aspen densities were observed in the clearcut, supporting our first hypothesis that aspen regeneration would be most persistent/successful where more light was available. First year aspen regeneration (131000 stems ha ${ }^{-1}$ ) was at the high end of the range of values reported in North America after clearcutting (Crouch 1983; Bella 1986; Brais et al. 2004; Lennie et al. 2009; Prévost and
DeBlois 2014). Ten years after harvesting, stem mortality was $90 \%$, with significantly higher densities in the clearcut than the strip and circle openings (Groot et al. 2009). Far fewer studies have documented the long term $(>26$ year) effects of aspen regeneration density after clearcutting; however, a recent study in two boreal mixedwood stands in Saskatchewan (Canada) reported an average decline in aspen densities after clearcutting from between 40000 to 200000 stems ha $^{-1}$ in year 1 to 2639 stems ha- $^{-1}$ in year 26 (Comeau 2021), which was comparable to our value of 2968 stems ha $^{-1}$ in year 26 .

The decline in aspen regeneration density with time since harvesting is consistent with other long-term clearcutting and partial harvesting studies (Man et al. 2008; Prévost and DeBlois 2014; Comeau 2021). Self-thinning is common in young aspen stands due to extremely high initial densities (Huffman et al. 1999) and intraspecific competition for 

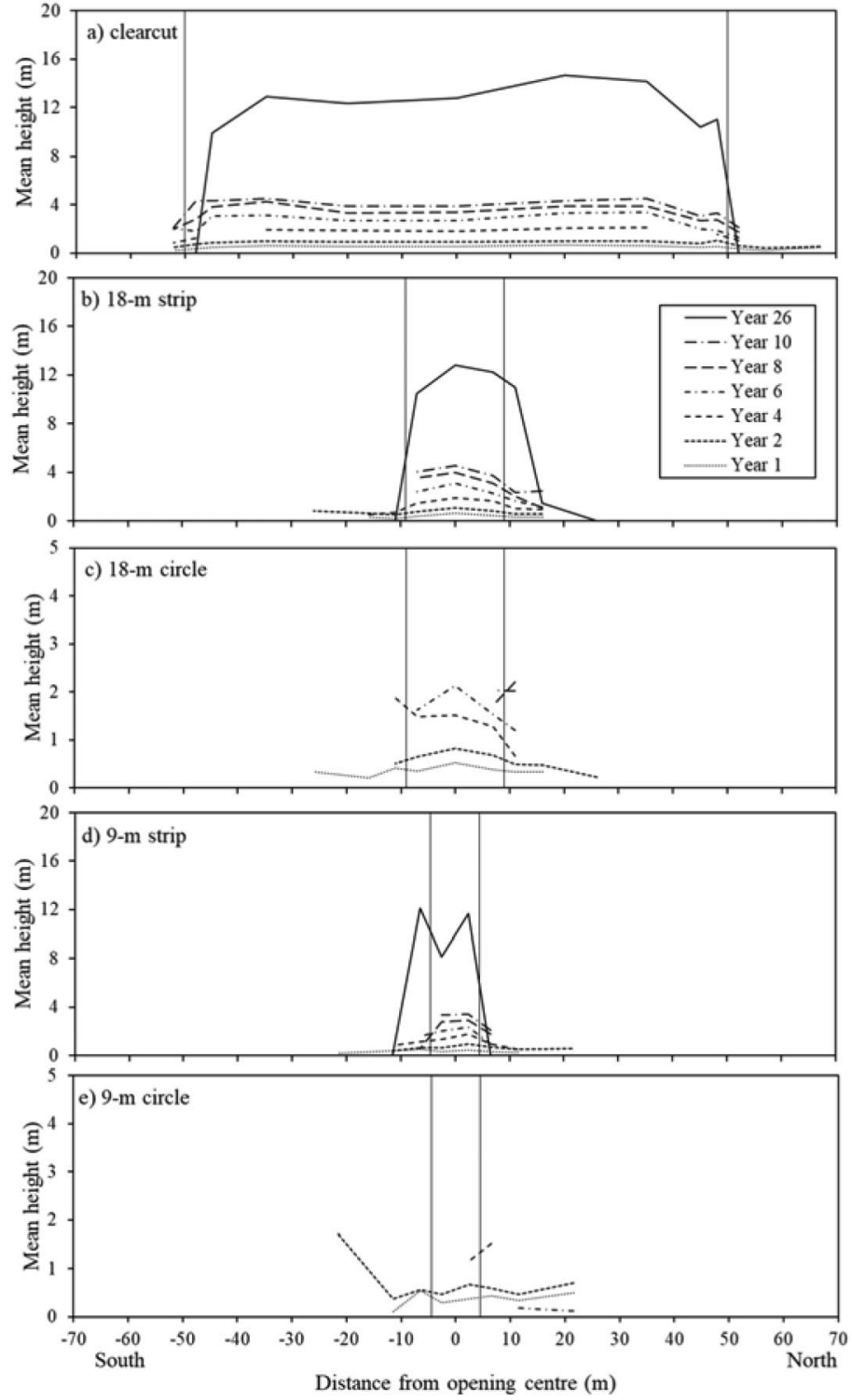

Fig. 5 Trembling aspen regeneration height (least square mean) in north-south transects across 5 opening types in a mixedwood forest stand in northeastern Ontario, Canada. Solid vertical lines indicate the edge of the opening. Note: adapted from Groot et al. 2009.

resources (light, nutrients, moisture) and space (Kweon and Comeau 2017). The mechanism for density reduction differs with opening size, with self-thinning occurring due to intraspecific competition among aspen suckers and interspecific competition between suckers and woody shrubs dominating in large openings (Doucet 1989; Frey et al. 2003; Man et al. 2008), and shading from adjacent trees in small openings (Groot et al. 2009). Additionally, mortality can be accelerated by interspecific competition for resources from conifers (Prévost and DeBlois 2014), insect attacks, disease, drought, wildfire, and herbivores (Kweon and Comeau 2017). For example, moose browsing can be more efficient than vegetation management using mechanical release treatments in diminishing the sapling density of intolerant hardwood species in some contexts (de Vriendt et al. 2020). While aspen mortality was likely due to competition for light in circular openings and space in clearcut openings, our design does not allow separating the potential effect of browsing.

The effect of opening type on density was more pronounced immediately after harvesting than after 26 years. By year 26, stem mortality exceeded $97 \%$, with no significant differences in aspen densities observed between the clearcut and strip openings. This change in treatment response is likely the result of the temporal dynamics of aspen regeneration, which has been documented in other clearcutting and partial harvesting studies (Man et al. 2009; Comeau 2021). For example, significant differences in aspen density and height between clearcutting and other (partial harvesting) treatments were found after 2-11 years (Brais et al. 2004; Man et al. 2008), but no significant differences were observed after 14 years (Man et al. 2009). Although densities between clearcut and strip openings did not differ significantly by year 26 , other early responses observed at the site persisted. For example, Groot et al. (1997) reported that more aspen regeneration occurred in the north half than in the south half of the openings, which was also observed at year 26 . Increased aspen regeneration in the north half of the openings was suggested to be caused by higher soil temperatures in the north half positions inducing more suckering (Groot et al. 1997). Higher light levels in the north half of the strip openings also favoured long-term development of the aspen suckers.

Our results at year 26 suggest that $18-\mathrm{m}$ diameter circular openings and 9-m wide strips are too small to ensure aspen densities required to produce a future aspen dominated stand $\left(0\right.$ stems ha $^{-1}$ in $18-\mathrm{m}$ circle openings and 421 stems ha $^{-1}$ in $9-\mathrm{m}$ strip openings). Based on our experimental conditions, circular openings must be substantially bigger than $18-\mathrm{m}$ in diameter $\left(254 \mathrm{~m}^{2}\right)$ and $18-\mathrm{m}$ wide strips are close to the minimum opening size needed to sustain aspen regeneration long term (Groot et al. 2009).

\section{Growth of disturbance regeneration}

By year 26, aspen height and DBH were highest in the clearcut and 18-m strip openings, which had higher initial light availability than the 9-m strip and circular openings, 
Table 2. Summary statistics for generalized additive models explaining aspen regeneration 26 years after harvesting in a mixedwood forest in northeastern Ontario, Canada, as a function of initial proportion of above canopy light (predictor variable). Edf = effective degrees of freedom. Test statistic refers to $F$ for Gaussian-distributed models and $\chi^{2}$ for Poisson-distributed models. Score refers to generalized cross-validation (GCV) score for Gaussian-distributed models and unbiased risk estimator (UBRE) for Poisson-distributed models. Scale estimate $[\phi]$ for Gaussian distributions is the residual standard error squared and for Poisson distributions $\phi=1$. DBH = diameter at breast height $(1.3 \mathrm{~m}) ; \mathrm{PACL}=$ initial proportion of above canopy light.

\begin{tabular}{llcccccccc}
\hline Response & $\begin{array}{c}\text { Distribu- } \\
\text { tion }\end{array}$ & $\mathbf{e d f}^{\dagger}$ & $\begin{array}{c}\text { Test } \\
\text { statistic }\end{array}$ & $\boldsymbol{p}^{\dagger}$ & $\begin{array}{c}\text { Adjusted } \\
\mathbf{R}^{\mathbf{2}}\end{array}$ & $\begin{array}{c}\text { Deviance } \\
\text { explained } \\
(\%)\end{array}$ & Score & $\begin{array}{c}\text { Scale } \\
\text { estimate }\end{array}$ & $\boldsymbol{n}$ \\
\hline Height & Gaussian & 8.81 & 4.9 & $<0.001$ & 0.163 & 20.3 & 11.426 & 10.82 & 184 \\
DBH & Gaussian & 7.09 & 1.6 & 0.090 & 0.047 & 8.5 & 10.812 & 10.33 & 184 \\
Density & Poisson & 6.64 & 184.2 & $<0.001$ & 0.414 & 47.0 & 0.148 & 1.00 & 262 \\
Volume & Poisson & 8.99 & 5788.0 & $<0.001$ & 0.456 & 56.5 & 33.970 & 1.00 & 262 \\
Basal area & Poisson & 8.92 & 814.6 & $<0.001$ & 0.446 & 53.5 & 4.470 & 1.00 & 262 \\
\hline
\end{tabular}

${ }^{\dagger}$ Refers to complexity and significance of the smooth terms

further supporting our hypothesis. The average heights of 12.6 and $12.9 \mathrm{~m}$ by year 26 in the clearcut and 18 -m strips are similar to average height values of $13.5 \mathrm{~m}$ reported by Comeau (2021) for aspen of similar ages and slightly above $\left(+0.1 \mathrm{~m} \mathrm{yr}^{-1}\right)$ the reported mean annual height increment for trembling aspen in northeastern boreal mixedwood forests (0.39-0.41 m yr-1) 7 to 14 years after clearcutting (Groot et al. 2009; Man et al. 2009, 2011).

In year 1, PACLs at opening centres were about $57 \%$ and $68 \%$ for the 9 - and $18-\mathrm{m}$ strips, compared with $26 \%$ and $55 \%$ for the 9-and $18-\mathrm{m}$ circles and $100 \%$ for the clearcut (Groot et al. 1997). Light levels in the strips were slightly higher than light levels in the circles of equal width due to the absence of trees in the east-west direction. By year 26, aspen height had decreased with decreasing initial above canopy light, in keeping with results of other partial harvesting studies (Man et al. 2008, 2009; Maleki et al. 2020). For example, Man et al. (2009) reported decreases in aspen height grown in a 50\% partial harvesting treatment (average height $=4.1 \mathrm{~m}$ ) compared to clearcut (average height $=5 \mathrm{~m}$ ) after 14 years; however, differences were not significant. The lack of treatment effect on aspen height in partial harvesting studies suggests that aspen growth and survival may be sustained under partial canopies; however, density must also be considered when comparing aspen regeneration height to opening type. Average aspen regeneration heights in the clearcut $(12.9 \mathrm{~m})$ and 18 -m strips $(12.6 \mathrm{~m})$ were similar by year 26 , despite the clearcut having almost twice the number of regeneration stems. The 9-m strip also maintained trees with an average height close to that of trees in the larger openings (10.1 m), but only nine stems occurred in this opening type. That tall aspen were maintained in the strips under a partial canopy is likely due to less intraspecific competition for light than in the clearcut.

Aspen basal area and volume were highest in plots with higher initial light availability, supporting our hypothesis. Reductions in overstory canopy through harvesting increase canopy opening and light transmittance to the understory (Man et al. 2008). The volume of regenerated aspen stands also declines with increasing overstory retention. For example, Gradowski et al. (2010) observed 50\% less aspen stand volume nine years after variable retention harvesting (leaving $20 \%$ of the original overstory) than after clearcutting. Bose et al. (2014b) reported a $25.6 \%$ decline in annual aspen volume increase of dominant and co-dominant trees after 12 years in control stands compared with stands that had two thirds of their total basal area removed. Decreased aspen volumes in these studies was thought to result from the combined influence of hormonal control and shading by mature stems on the establishment and growth of regenerating aspen suckers (Gradowski et al. 2010) and competition for resources in stands with a third or less basal area removed (Bose et al. 2014b). By year 26, self-thinning had already occurred in our stand and competition for resources resulting in decreases in aspen volume and basal area was unlikely due to low regeneration densities (less than 3000 stems ha $^{-1}$ in all opening types). The relatively stable low levels of aspen volume and basal area observed at less than 80\% PACL in our study were likely a result of decreased regeneration and growth due to hormone control and shading by mature stems adjacent to the openings.

\section{Vegetation in openings}

Many new aspen stems ( $<1.3 \mathrm{~m}$ tall) were observed inside the openings, and densities generally decreased with increasing canopy cover. Pulses of aspen stems occurring in high densities initiating under established overstories have been observed in other field studies after clearcutting (Macdonald and Thompson 2003). These stems are generally short lived and their mortality has been attributed to lack of available light resulting from a height disadvantage (Perala 1991; Man et al. 2009).

Regenerating overstory tree cover in openings was dominated by aspen (62\%). This was expected since the parent stand was aspen dominant (84\% of the stand basal area) before harvesting, allowing for a greater bud bank and potential to produce suckers (Gradowski et al. 2010). However, the medium openings (18-m circles and 9-m strips) were dominated by conifers in the regenerating overstory and the 9-m circles were devoid of canopy trees (except for two conifer stems). In boreal mixedwoods, shade-tolerant conifers such as balsam fir and spruce can survive and grow slowly in the 

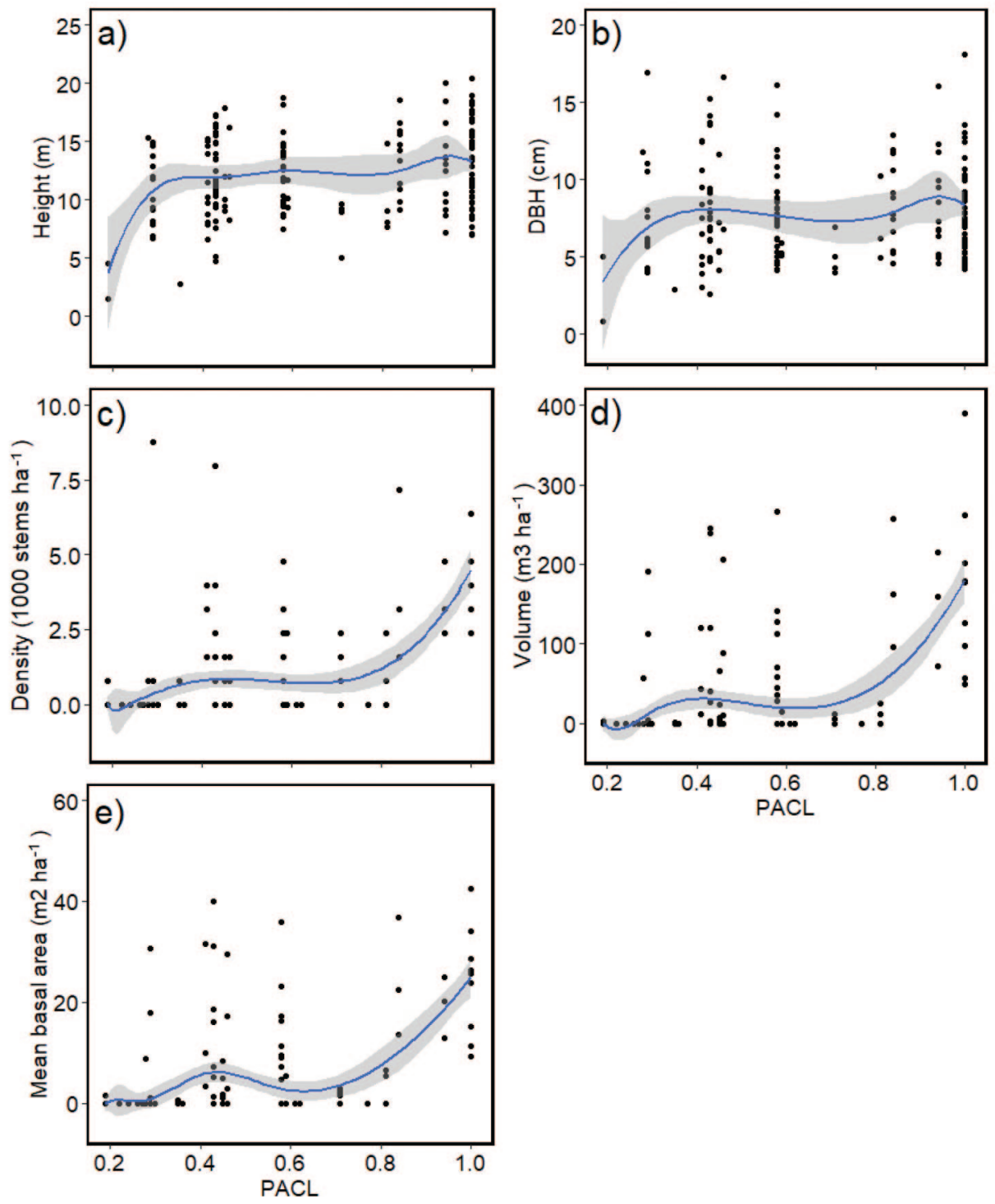

Fig. 6 Generalized additive models for aspen regeneration a) height, b) diameter at breast height (DBH; 1.3 m), c) density, d) volume, and e) basal area by proportion of above canopy light (PACL) at time of harvest, 26 years after openings were established in a mixedwood forest stand in northeastern Ontario, Canada. For height and DBH, each circle represents an individual aspen stem ( $n=184$ ). For density, volume, and basal area, each circle represents an individual plot ( $n=262$ ). The solid line represents a smooth on the predictor variable and shading the standard error.

understory and intermediate canopy until the initial cohort decline/die from disturbance (Chen and Popadiouk 2002). In northwestern Quebec, significant increases in canopy opening and gap size with forest tent caterpillar outbreak intensity in stands dominated by trembling aspen were found (Moulinier et al. 2013) and spruce budworm outbreak could accelerate the transition of a mixedwood to a self-replacing fir stand where balsam fir saplings are abundant (Baskerville 1975). In our stand, no significant outbreak activity occurred over the last 10 years (Ministry of Natural Resources and Forestry 2020) and shading from adjacent trees outside the medium openings likely increased mortality of aspen regeneration, allowing for shade-tolerant conifers such as balsam fir to grow in canopy gaps and dominate the overstory by year 26. In the larger openings (clearcut and 18-m strips), more aspen regeneration was able to survive to year 26 and most of the conifers remained in the understory.

Woody shrub cover seemed to be highest in medium openings (9-m strips and $18-\mathrm{m}$ circles), although no treatment effect was evident, providing support for our third hypothesis that shade-tolerant shrubs would be abundant throughout the openings. Mid-term (year 10) results at this 


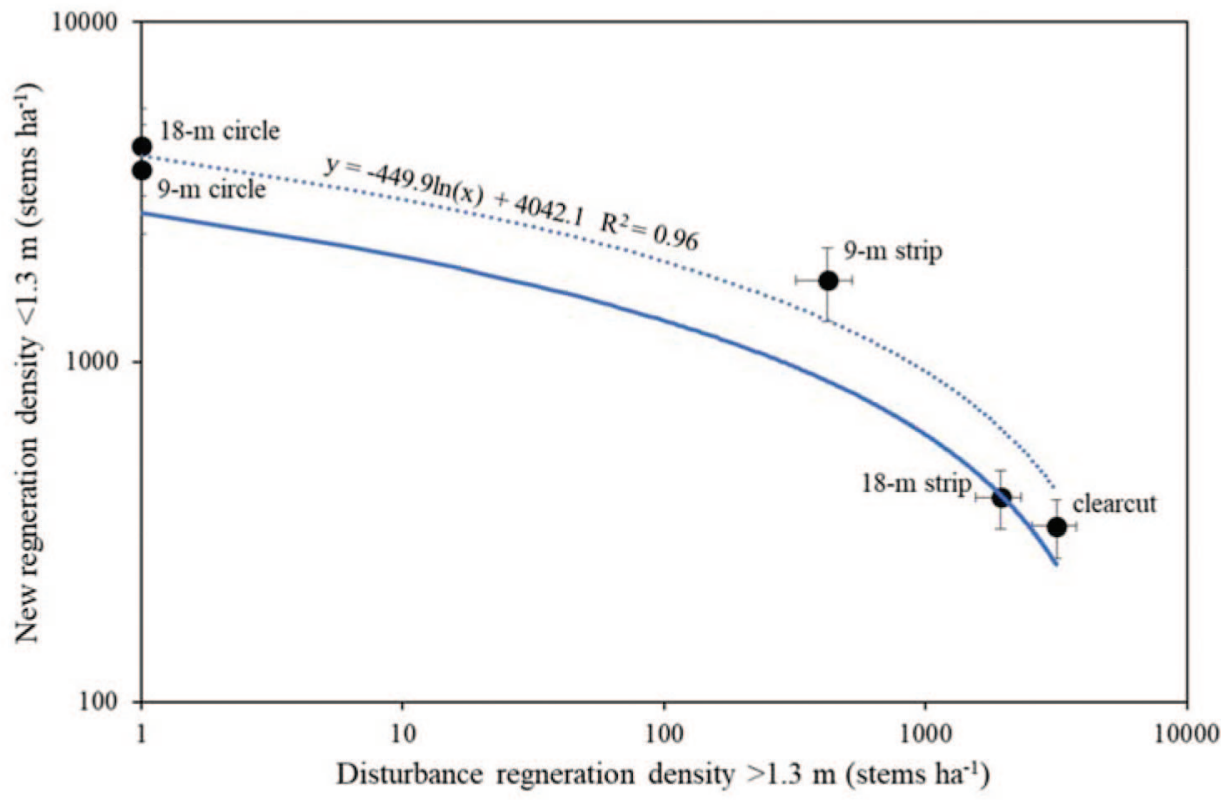

Fig. 7 Average ( \pm standard error of the mean) new regeneration $(<1.3 \mathrm{~m}$ height) vs. disturbance regeneration ( $>1.3 \mathrm{~m}$ height) density (log scale) in a mixedwood forest stand in northeastern Ontario, Canada. Dashed line is least square fit to new regeneration density by opening type; solid line is smooth on the predictor variable calculated by the generalized additive model (see Table 2; $n=90$ ).

study site indicated a dense layer of shrubs (mainly Corylus cornuta and Acer spicatum) in openings where aspen regeneration was sparse/absent (9-m strips and 9- and 18-m circles; Groot et al. 2009). Decreased soil temperature conditions resulting from thick insulating litter of competitors can significantly reduce the growth of young aspen stems (Hogg and Lieffers 1991; Landhäusser and Lieffers 1998). By year 26, medium openings (9-m strips and $18-\mathrm{m}$ circles) were dominated by balsam fir and white spruce in the regenerating overstory, which was likely due to suppression of aspen sucker development by shrubs decreasing soil temperature conditions in earlier years at the site (Groot et al. 1997).

\section{Management implications}

If the management goal is to regenerate trembling aspen, the gaps in the overstory created by small-scale disturbances (i.e., circles 9-m and $18-\mathrm{m}$ in diameter or strips 9-m wide) are not large enough to allow for aspen densities required to produce a future aspen dominated stand. In our experimental conditions, aspen regeneration and growth after 26 years was adequate in larger openings (clearcut and 18 -m strips) with initial light levels of $>80 \%$ full light. This finding supports the traditional view that aspen is best managed under the clearcut silvicultural system (Doucet 1989) and suggests shorter-term studies on aspen regeneration (Groot et al. 1997,2009 ), as well as direction in Ontario's current silviculture guide (i.e., regeneration established in $>70 \%$ full sunlight using the clearcut silviculture system; Ministry of Natural Resources and Forestry 2015), may underestimate how much light is needed for adequate aspen regeneration. Due to the temporal nature of aspen regeneration, longer-term $(>25$ years) studies are needed to assess the fate of regenerated aspen following small- to medium-scale disturbances (creation of canopy gaps).

While aspen regeneration did not survive in the smaller gaps, there was good initial regeneration. Therefore, if the management plan for the stand is to create an uneven-aged structure, the circular gaps or narrower (9-m) strips could be used, provided that they were expanded before significant mortality occurred. This would be a novel way of managing aspen but increasing structural diversity may increase the resilience of the stand to disturbance. This may also be a way of managing aspen/mixedwood stands where there is significant pressure to avoid clearcutting.

The management implications of this study apply to relatively young, aspen-dominated stands in northeastern Ontario. Before the harvesting treatment, at about stand age 40 , aspen accounted for $84 \%$ of stand basal area. Aspen-dominated stands have a larger mass of roots that can support the next generation of aspen suckers, stimulating their early growth (Landhäusser and Lieffers, 2002) and resulting in higher site indices for aspen in those areas (Gradowski et al. 2010). Younger stands may have more vigorous root systems allowing for increased regeneration and growth (Gradowski 
et al. 2010). Similar opening treatments in mixedwood stands that are conifer-dominated or older may result in less aspen re-suckering and growth than occurs in young aspen-dominated mixedwoods.

At our site, 26 years after treatment, the mixedwood stand (beyond the openings) was about 65 years old. When aspen reaches about 60 years, canopy trees begin to senesce, and the stand begins to naturally convert to a more softwood-dominated composition over several decades (Chen and Popadiouk 2002). Future assessments at this site may allow for continued monitoring on the temporal dynamics of aspen regeneration and help to answer questions about how gap dynamics affects boreal mixedwoods as mature trees in the stand decline and die.

\section{Acknowledgements}

Jim Wood initiated this study in 1993 by planning, installing and measuring the sample plots. We thank John Schnare, Amy Bolduc, Derissa Vincentini, Riley Stobie, Erika Mihell, Justin Viljakainen, and Jacob Roy for their help in collecting the $26^{\text {th }}$ year measurements. We extend our thanks to Eric Searle for consulting on the data analysis, and Mike Brienesse, Lisa Buse, Rongzhou Man, Gordon Kayahara (NDMNRF) and Michael Hoepting (CFS) for their thoughtful reviews of the draft manuscript. This study was funded by the Northern Ontario Development Agreement, Northern Forestry Program and the Ontario Ministry of Northern Development, Mining, Natural Resources and Forestry.

\section{References}

Barnes, B. 1975. Phenotypic variation of trembling aspen in western North America. For. Sci. 21(3): 319-328. doi:10.1093/ forestscience/21.3.319.

Baskerville, G. 1975. Spruce budworm: Super silviculturist. For. Chron. 51(4): 138-140. doi:10.5558/tfc51138-4.

Bell, F., D. Pitt, A. Morneault and S. Pickering. 1999. Response of immature trembling aspen to season and cut height. N. J. Appl. For. 16(2): 108-113. doi:10.1093/njaf/16.2.108.

Bella, I. 1986. Logging practices and subsequent development of aspen stands in east-central Saskatchewan. For. Chron. 62(2): 8183. doi:10.5558/tfc62081-2.

Bergeron, Y., H. Chen, N. Kenkel, A. Leduc and S. Macdonald. 2014. Boreal mixedwood stand dynamics: Ecological processes underlying multiple pathways. For. Chron. 90(2): 202-213. doi:10.5558/tfc2014-039.

Berrill, J.-P., C. Dagley, S. Coppeto and S. Gross. 2017. Curtailing succession: Removing conifers enhances understory light and growth of young aspen in mixed stands around Lake Tahoe, California and Nevada, USA. For. Ecol. Manag. 400: 511-522. doi:10.1016/ j.foreco.2017.06.001.

Bose, A., B. Havey and S. Brais. 2014a. Sapling recruitment and mortality dynamics following partial harvest in aspen-dominated mixedwoods in eastern Canada. For. Ecol. Manag. 329: 37-48. doi:10.1016/j.foreco.2014.06.004.

Bose, A., S. Brais and B. Harvey. 2014b. Trembling aspen (Populus tremuloides Michx.) volume growth in the boreal mixedwood: Effects of partial harvesting, tree social status, and neighborhood competition. For. Ecol. Manag. 327: 209-220. doi:10.1016/ j.foreco.2014.05.003.

Brais, S., B. Harvey, Y. Bergeron, C. Messier, D. Greene, A. Belleau and D. Pare. 2004. Testing forest ecosystem management in boreal mixedwoods of northwestern Quebec: Initial response of aspen stands to different levels of harvesting. Can. J. For. Res. 34(2): 431-446. doi:10.1139/x03-144.
Carlson, D. and A. Groot. 1997. Microclimate of clear-cut, forest interior, and small openings in trembling aspen forest. Agric. For. Meteorol. 87(4): 313-329. doi:10.1016/S0168-1923(95)02305-4. Chen, H. and R. Popadiouk. 2002. Dynamics of North American boreal mixedwoods. Environ. Rev. 10(3): 137-166. doi:10.1139/ A02-007.

Comeau, P. 2021. Effects of thinning on dynamics and drought resistance of aspen-white spruce mixtures: Results from two study sites in Saskatchewan. Front. For. Glob. Change. 3: 621752. doi:10.3389/ffgc.2020.621752.

Crouch, G. 1983. Aspen regeneration after commercial clearcutting in southwestern Colorado. J. For. 81(5): 316-319. doi:10.1093/jof/ 81.5.316.

Cumming, S., F. Schmiegelow and P. Burton. 2000. Gap dynamics in boreal aspen stands: Is the forest older than we think? Ecol. Appl. 10(3): 744-759. doi:10.1890/1051-0761(2000)010[0744:GDIBAS] 2.0.CO;2.

DesRochers, A. and V.J. Lieffers. 2001. The coarse-root system of mature Populus tremuloides in declining stands in Alberta, Canada. J. Veg. Sci. 12(3): 355-360. doi:10.2307/3236849.

de Vriendt, L., N. Thiffault, A.A. Royo, M. Barrette and J.P. Tremblay. 2020. Moose browsing tends spruce plantations more efficiently than a single mechanical release. Forests 11(11): 1138. doi: $10.3390 /$ f11111138.

Doucet, R. 1989. Silviculture of aspen regeneration. For. Chron. 65(1): 23-27. doi:10.5558/tfc65023-1.

Einspahr, D. and G. Wyckoff. 1990. North American aspen: Timber supply, utilization, and research. N. J. Appl. For. 7(4): 168-171. doi:10.1093/njaf/7.4.168

Eliasson, L. 1971. Growth regulators in Populus tremula IV. Apical dominance and suckering in young plants. Physiol. Plant. 25(2): 263-267. doi:10.1111/j.1399-3054.1971.tb01440.x.

Farmer, R. 1962. Aspen root sucker formation and apical dominance. For. Sci. 8(4): 403-410. doi:10.1093/forestscience/8.4.403.

Fraser, E., V. Liefers, S. Landhäusser and B. Frey. 2002. Soil nutrition and temperature as drivers of root suckering in trembling aspen. Can. J. For. Res. 32(9): 1685-1691. doi:10.1139/x02-080.

Frey, B., V. Lieffers, S. Landhäusser, P. Comeau and K. Greenway. 2003. An analysis of sucker regeneration of trembling aspen. Can. J. For. Res. 33: 1169-1179. doi:10.1139/X03-053.

Gradowski, T., V. Lieffers, S. Landhäusser, D. Sidders, J. Volney and J. Spence. 2010. Regeneration of Populus nine years after variable retention harvest in boreal mixedwood forests. For. Ecol. Manag. 259(3): 383-389. doi:10.1016/j.foreco.2009.10.033.

Groot, A., D. Carlson, R. Fleming and J. Wood. 1997. Small openings in trembling aspen forest: Microclimate and regeneration of white spruce and trembling aspen. Available from Natural Resources Canada, Canadian Forest Service, Great Lakes Forestry Centre, Sault Ste. Marie, O.N. NODA/NFP Technical Report TR$47.25 \mathrm{p}$.

Groot, A., R. Man and J. Wood. 2009. Spatial and temporal patterns of Populus tremuloides regeneration in small forest openings in northern Ontario. For. Chron. 85(4): 548-557. doi:10.5558/ tfc85548-4.

Guisan, A., T. Edwards and T. Hastie. 2002. Generalized linear and generalized additive models in studies of species distributions: Setting the scene. Ecol Modell. 157(2-3): 89-100. doi:10.1016/ S0304-3800(02)00204-1.

Hogg, E.H. and V.J. Lieffers. 1991. The impact of Calamagrostis canadensis on soil thermal regimes after logging in northern Alberta. Can. J. For. Res. 21(3): 387-394. doi:10.1139/x91-048.

Huffman, R., M. Fajvan and P. Wood. 1999. Effects of residual overstory on aspen development in Minnesota. Can. J. For. Res. 29(2): 284-289. doi:10.1139/x98-202.

Hurlbert, S. 1984. Pseudoreplication and the design of ecological field experiments. Ecol. Monogr. 54(2): 187-211. doi:10.2307/ 1942661 . 
Kabzems, R. 2001. Regenerating boreal mixedwoods: Three-year results of a group shelterwood silviculture system in trembling aspen - white spruce stands. Available from the British Columbia Forest Service, Ministry of Forests, Prince George, B.C. Note \#PG-24. Kweon, D. and P. Comeau. 2017. Effects of climate on maximum size-density relationships in western Canadian trembling aspen stands. For. Ecol. Manag. 406: 281-289. doi:10.1016/j.foreco. 2017.08.014.

Landhäusser, S. and V. Lieffers. 2001. Photosynthesis and carbon allocation of six boreal tree species grown in understory and open conditions. Tree Physiol. 21(4): 243-250. doi:10.1093/treephys/ 21.4.243.

Lavertu, D., Y. Mauffette and Y. Bergeron. 1994. Effect of stand age and litter removal on the regeneration of Populus tremuloides. J. Veg. Sci. 5(4): 561-568. doi:10.2307/3235983.

LeBlanc, P. 2014. Incorporating multi-cohort old aspen and mixedwood dynamics into a long-term forest management plan. For. Chron. 90(1): 50-58. doi:10.5558/tfc2014-010.

Lennie, A., S. Landhäusser, V. Lieffers and D. Sidders. 2009. Regeneration of aspen following partial and strip understory protection harvest in boreal mixedwood forests. For. Chron. 85(4): 631638. doi:10.5558/tfc85631-4.

MacDonald, G. and D. Thompson. 2003. Responses of planted conifers and natural hardwood regeneration to harvesting, scalping, and weeding on a boreal mixedwood site. For. Ecol. Manag. 182(13): 213-230. doi:10.1016/S0378-1127(03)00047-1.

Maleki, K., F.N. Allogo and B. Lafleur. 2020. Natural regeneration following partial and clear-cut harvesting in mature aspen-jack pine stands in eastern Canada. Forests. 11: 741. doi:10.3390/f11070741. Man, R. and V. Lieffers. 1999. Are mixtures of aspen and white spruce more productive than single species stands? For. Chron. 75(3): 505-513. doi:10.5558/tfc75505-3.

Man, R., J. Rice and G. MacDonald. 2009. Long-term response of planted conifers, natural regeneration, and vegetation to harvesting, scalping, and weeding on a boreal mixedwood site. For. Ecol. Manag. (258): 1225-1234. doi:10.1016/j.foreco.2009.06.012.

Man, R., J. Rice and G. MacDonald. 2011. Early effects of pre- and post-harvest herbicide application and partial cutting in regenerating aspen - jack pine mixtures in northeastern Ontario. Can. J. For. Res. 41: 1082-1090. doi:10.1139/X11-021.

Man, R., G. Kayahara, J. Rice and G. MacDonald. 2008. Elevenyear responses of a boreal mixedwood stand to partial harvesting: Light, vegetation, and regeneration dynamics. For. Ecol. Manag. 255: 697-706. doi:10.1016/j.foreco.2007.09.043.

Ministry of Natural Resources and Forestry. 2015. Forest management guide to silviculture in the Great Lakes-St. Lawrence and boreal forests of Ontario [online]. Publication No.109091_U. Available from https://www.ontario.ca/page/forest-management-guidesilviculture-great-lakes-st-lawrence-and-boreal-forests-ontario [accessed 4 May 2021].

Ministry of Natural Resources and Forestry. 2020. Forest health conditions in Ontario 2019 [online]. Available from https://files. ontario.ca/mnrf-forest-health-conditions-report-2019-en-2020-0731.pdf [accessed 15 June 2021].

Moulinier, J., F. Lorenzetti and Y. Bergeron. 2011. Gap dynamics in aspen stands of the clay belt of northwestern Quebec following a forest tent caterpillar outbreak. Can. J. For. Res. 41: 1606-1617. doi:10.1139/X11-075.
Moulinier, J., F. Lorenzetti and Y. Bergeron. 2013. Effects of a forest tent caterpillar outbreak on the dynamics of mixedwood boreal forests of eastern Canada. Écoscience. 20(2): 182-193. doi:10.2980/ 20-2-3588.

Namroud, M.-C., A. Park, F. Tremblay and Y. Bergeron. 2005. Clonal and spatial genetic structures of aspen (Populus tremuloides Michx.). Mol. Ecol. 14: 2969-2980. doi:10.1111/j.1365-294X. 2005.02653.x.

Perala, D. 1990. Populus tremuloides Michx. Quaking aspen. In: R. Burns and B. Honkala (Eds.). Silvics of North America: Volume 2, Hardwoods. pp. 555-569. Available from the U.S. Department of Agriculture, Forest Service, Washington, D.C. Agriculture Handbook No. 654.

Perala, D. 1991. Renewing decadent aspen stands. In S. Navratil and P. Chapman (Eds.). Aspen Management for the 21st century. Proceedings of a Symposium: Edmonton, Alberta, 20-21 November 1990. pp. 77-82. Forestry Canada, Northwest Region, Northern Forestry Center and Poplar Council of Canada, Edmonton, AB.

Perala, D. and J. Russell. 1983. Aspen. In: R. Burns (Ed.). Silviculture systems for the major forest types of the United States. pp. 113115. Available from the United States Department of Agriculture, Forest Service, Washington, D.C. Agricultural Handbook No. 445.

Peterson, R. 1975. The initiation and development of root buds. In: J. Torrey and D. Clarkson (Eds.). The development and function of roots. pp. 125-161. Academic Press, New York, NY.

Pinno, B. and R. Errington. 2015. Maximizing natural trembling aspen seedling establishment on a reclaimed boreal oil sands site. Ecol. Restor. 33(1): 43-50. doi:10.3368/er.33.1.43.

Prévost, M. and J. DeBlois. 2014. Shelterwood cutting to release coniferous advance growth and limit aspen sucker development in a boreal mixedwood stand. For. Ecol. Manag. 323: 148-157. doi:10.1016/j.foreco.2014.03.015.

R Core Team. 2020. R: a language and environment for statistical computing. R Foundation for Statistical Computing, Vienna, Austria. Available from https://www.R-project.org/ [accessed 9 January 2021]. Rogers, P. 2002. Using forest health monitoring to assess aspen forest cover change in the southern Rockies ecoregion. For. Ecol. Manag. 155(1-3): 223-236. doi:10.1016/S0378-1127(01)00560-6.

Rogers, P., S. Landhäusser, B. Pinno and R. Ryel. 2014. A functional framework for improved management of western North American aspen (Populus tremuloides Michx.). For. Sci. 60(2): 345359. doi:10.5849/forsci.12-156.

Rowe, J.S. 1972. Forest Regions of Canada. Available from Fisheries and Environment Canada, Canada Forest Service, Ottawa, O.N. 172 p. Schier, G., J. Jones and R. Winokur. 1985. Vegetative regeneration. In: N.V. DeByle and R.P. Winokur (Eds.). Aspen: Ecology and management in the western United States. pp. 29-33. Available from the Rocky Mountain Forest and Range Experiment Station, Fort Collins, Colo. USDA Forest Service General Technical Report RM-119.

Solarik, K., W. Volney, V. Lieffers, J. Spence and A. Hamann. 2012. Factors affecting white spruce and aspen survival after partial harvest. J. Appl. Ecol. 49(1): 145-154. doi:10.1111/j.1365-2664.2011. 02089.x.

Williams, K. 1972. The relationship of soil temperature and cytokinin production in aspen invasion. M.Sc. thesis, The University of New Mexico, Albuquerque, N.M. 39 p. 